\title{
Incivility Beyond the Classroom Walls
}

\author{
Wendy L. Bjorklund, PhD \\ Assistant Professor, Department of Communication Studies \\ St. Cloud State University \\ Diana L. Rehling, PhD \\ Professor, Department of Communication Studies \\ St. Cloud State University
}

Classroom incivility has become a major concern in higher education. Faculty and students frequently interact outside of class, and the lack of civility in those interactions can influence the relationship between students and faculty and impact classroom dynamics. Based on a survey of faculty at a Midwestern public university, this study reports that faculty experience a fair amount of moderately inappropriate student behavior outside the classroom, including missing scheduled appointments, wearing revealing clothing, and requesting a grade change. These results can help faculty and administrators guide students toward more appropriate behavior and create better relationships between faculty and students.

The decline of civility in US society has become a hot topic over the past two decades, with scholars and reporters addressing everything from the loss of civility in the workplace to the absence of manners on mass transit (Jacoby, 1999; Lunday, 2007). Looking beyond the definition of civility as connected to citizenship and moving towards the more common notion of civility as related to "behavior proper to the intercourse of civilized people" (Rookstool, 2007), the laments are about how we interact with one another. Within higher education, the focus has been primarily upon declining civility in the classroom (Alexander-Snow, 2004; Dechter, 2007; Feldmann, 2001; Sorcinelli, 1994). Scholars note that classroom incivility takes a toll on student learning and can even impact students' respect and regard for the academic institution itself (Feldmann, 2001; Hirschy \& Braxton, 2004; Morrissette, 2001). Furthermore, and more relevant to the present study, faculty members report that dealing with student incivility is discouraging and disheartening and can impact their relationships with students (Appleby, 1990; Boice, 1996; Clark \& Spring, 2007; Jones, 2004). Some faculty members indicate

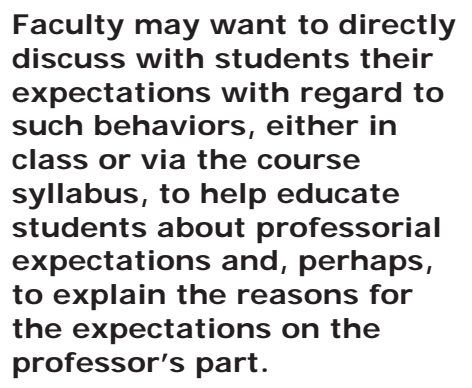
student incivility has even caused them to reconsider their choice of profession (Boice, 1996). In addition, new and younger faculty, female faculty, and faculty of color are more likely to be the targets of incivility (Boice, 1996; Alexander-Snow, 2004). To deal with such matters, institutions have begun to create new student programs, codes of conduct, and other measures aimed at educating students about appropriate behavior and informing them of the possible consequences of infractions (Dechter, 2007; Young 2003).

Research on incivility in higher education has concentrated largely upon faculty perceptions of students' behavior in the classroom setting (Amada, 1999; Appleby 1990; Boice, 1996; Feldmann, 2001; Indiana University Center for Survey Research, 2000). Yet many interactions between faculty and students take place outside the context of formal class sessions, and the lack of civility in those interactions can also strongly influence the relationship between students and faculty members, impact the dynamics of the classroom, and influence the faculty members' attitudes toward their job and profession. 
Furthermore, understandings about civility, while ideally communal and widely recognized, are also perceptual and negotiated. The most egregious behaviors, such as racial slurs or sexual harassment, may be generally recognized as unacceptable, but in some instances the boundaries between civil and uncivil, appropriate and inappropriate, are less clear. What one faculty member may find exceptionally rude may register as a minor annoyance with another. What members of one generation consider acceptable may be perceived as disrespectful to many members of another generation. And yet each individual assigns meaning and acts out of their sense of what behavior is appropriate.

The hallways of academia are filled with anecdotes of inappropriate student behavior outside the classroom-behavior that in some studies faculty and researchers have labeled "uncivil" (e.g., Appleby, 1990; Indiana University Center for Survey Research, 2000). Yet no formal research has been aimed particularly at the topic of inappropriate or uncivil behavior outside the classroom walls. This gap in the research means that there is no clear sense, for faculty or students, as to what faculty consider appropriate behavior in interactions between faculty and students outside the classroom walls-thus creating a situation ripe for confusion and misunderstandings. The present study is intended to help fill that gap and provide information to faculty, students, and administrators about faculty perceptions of the kinds and frequency of inappropriate behaviors faculty encounter with students outside the classroom. ${ }^{1}$ Toward that end, we posed two research questions: What behaviors outside the classroom do faculty perceive as inappropriate in their interactions with students? And to what extent do faculty perceive these inappropriate behaviors to be occurring in their interactions with students outside the classroom?

\section{Methods}

\section{Sample}

One hundred fifty-three faculty participants were recruited from a Midwestern university through an emailed letter sent via the faculty list serve. The list serve included approximately 1,300 faculty members (this number varies slightly from day to day because faculty members may join or leave the list serve whenever they choose to do so). ${ }^{2}$ A duplicate letter also was sent to faculty members via campus mail. Faculty participants ranged in age from 25 to 67 years of age, with a mean age of 48.58 (standard deviation .857), and a median age of 49.00. Faculty had a mean of 14.64 (standard deviation 9.697) years of experience and a median of 12.00 years of experience teaching at the college level. Participants included 52 men and 90 women.

\section{Procedure}

The recruitment letter included a link to an online survey constructed using SurveyMonkey software. The survey was pretested through a pilot study in the semester prior to the one in which data were collected for the actual study. In addition to providing demographic information, participants rated how frequently they observed students engaging in various inappropriate behaviors outside of the classroom, along with the degree of inappropriateness of those behaviors. "Inappropriate" was defined for the participants as "student behavior which is not suited to effective professional interactions, including such behaviors as those which put the instructor in an awkward position, place unreasonable demands for time and attention on the instructor, place demands on the instructor that are not part of his/her responsibilities, insult the instructor, etc."

InSight: A J ournal of Scholarly Teaching 


\section{Variables}

Degree of inappropriateness of student behaviors. In this study, the researchers separated uncivil classroom behaviors from behaviors students exhibit outside of the classroom that seem to be inappropriate, or rude, to their professors. A list of inappropriate behaviors that occur outside of the classroom was derived from a review of literature on student incivility (e.g., Appleby, 1990; Indiana University Center for Survey Research, 2000), and to that list were added a few behaviors the researchers found to be particularly disturbing. Two additional behaviors that were clearly appropriate were added to the list (for a total of 14 items), and this list was used in the survey. The inclusion of these two appropriate behaviors allowed the researchers to identify participants who were not reading the items, but were simply rating each item identically. Participants were asked "To what degree do you consider these behaviors to be inappropriate?" They used a 5point Likert-type scale to evaluate each behavior. This scale ranged from " $1=$ not inappropriate at all" to " $5=$ extremely inappropriate".

Frequency of inappropriate student behaviors. Participants also were asked to rate how frequently they observed each of the 14 student behaviors using a 5 -point Likert-type scale. This scale ranged from " $1=$ never" to " $5=$ frequently".

\section{Results}

In order to answer the first research question focused upon identifying inappropriate behaviors, the mean rating for the degree of inappropriateness for each student behavior was calculated, and the behaviors were then ranked in order of inappropriateness, from most inappropriate to least inappropriate (see Table 1). Next, a one-way repeated-measures analysis of variance (ANOVA) was calculated, which indicated that there was a significant difference in the degree to which the participants perceived the inappropriateness of the individual behaviors $(F=$ 2,699.86, df $=1,123, \mathrm{p}<.01$, medium effect size, Eta $=.98$ ).

Faculty participants rated no student behaviors with a mean of 4 or above ( 4 = very inappropriate). They rated seven behaviors, however, with a mean of 3 or above ( $3=$ moderately inappropriate). They also rated four behaviors with a mean of 2 or below ( 2 = somewhat inappropriate). The behaviors rated 2 or below included (in descending order): "sending e-mail or voicemails requesting you call them back," "requesting the instructor inform them of their grade at the end of the semester," "arriving at a scheduled meeting on time," and "requesting letters of recommendation with plenty of lead time." The lowest rated behaviors were those not intended to be perceived as inappropriate.

The study's second research question focused on the frequency of the inappropriate behaviors. The mean rating for the frequency by which each behavior was observed was calculated, and the behaviors were then ranked in order of frequency, from most frequent to least frequent (see Table 2). Next, a one-way repeated-measures ANOVA was calculated, which indicated that there was a significant difference in the frequency by which the participants perceived the individual inappropriate behaviors $(F=2,306.77$, df $=1,125, p<.01$, medium effect size, Eta $=.97$ ).

Faculty gave no student inappropriate behavior a mean frequency rating of 4 or more. Four behaviors earned mean ratings over 3 (in descending order): "arriving at a scheduled appointment on time," "asking if they missed anything important," "requesting letters of recommendation with plenty of lead time," and "sending an e-mail or voicemails requesting you call them back." Two of the three behaviors observed most frequently were not intended to be perceived as inappropriate. No inappropriate behaviors received a mean rating of less than 2. So, while it appears that although faculty participants do not observe inappropriate 
student behaviors very frequently, they do observe those behaviors on a consistent basis.

\section{Discussion}

Faculty perceived seven of the behaviors included in the study as moderately to very inappropriate (3.25 or higher on a 5 point scale). With the exception of "insisting you force register them into an already closed course," the same behaviors were perceived as happening at a rate of 2.42 or higher on a 5point scale, indicating they are occurring with regularity. If we take these results in total, we can conclude that, in faculty members' perceptions, students are indeed acting inappropriately on a fairly regular basis. The picture that emerges from the data is less a mortal blow delivered to the faculty-student relationship by some egregious acts of incivility by students than it is a threat to the health of the relationship from a thousand little paper cuts.

Three of those behaviors perceived as most inappropriate-missing a scheduled appointment, wearing apparel with explicit language or images, and insisting that you force register them into a closed course were seen as considerably more egregious than the other behaviors listed. Administrators and staff designing new student sessions and other programs to address civility would be well advised to include discussions or warnings about these behaviors in particular, since most faculty clearly find them inappropriate. In addition, faculty may want to directly discuss with students their expectations with regard to such behaviors, either in class or via the course syllabus, to help educate students about professorial expectations and, perhaps, to explain the reasons for the expectations on the professor's part.

Other behaviors, such as a student

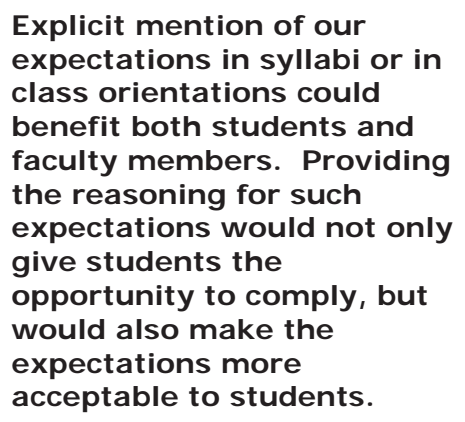

asking if they missed anything important or turning a paper in late and asking not to be penalized, were not generally perceived as the most problematic behaviors listed, but were still seen as quite inappropriate (3.37 and 3.74 respectively) and as occurring fairly frequently (3.58 and 2.88 ). Given that faculty are regularly advised to clearly express expectations for classroom behavior in the class syllabus or to discuss their expectations early on in a class (Carbone, 1999; Morrisette, 2001; Sorcinelli, 1994), faculty might consider articulating their expectations in their syllabus or early classroom discussion for these areas outside of the classroom as well. These interactions take place outside of public view, often after class or in the faculty member's office where other students would not observe other students' behavior or a faculty member's response to that behavior; therefore, directly addressing these issues may be particularly important in educating students to faculty expectations. Such discussions might not only outline the faculty member's expectations, but might also explain the reasoning and significance of the expectations in the faculty member's eyes.

Although some behaviors listed in the study's survey may not on average have been perceived as particularly inappropriate by the study's participants, the data indicate all of the behaviors are viewed as inappropriate by some of the professors in the study. For example, "Sending e-mail or voicemails requesting you to call them back" received a mean score of 1.98 in the study, suggesting it is not generally seen as particularly inappropriate. Yet, $6.1 \%$ of faculty members in the survey rated the behavior a " 5 " ("extremely inappropriate"), and another $9.1 \%$ rated it a "4" ("very inappropriate"). Appropriateness and civility, grounded as they are in our perceptions and our expectations, can be very slippery concepts, upon which all faculty do not agree (Bjorklund \& Rehling, 2010). In the case of behaviors where there does not seem to be clear consensus, explicitly stating our preferences 
to students may be particularly important in order to avoid unnecessary tensions between the faculty member and students. Within the context of a classroom, students can take social cues from each other regarding what behavior is appropriate. Outside of the classroom, it may be difficult for a student to discern whether a behavior will be perceived as appropriate, and when it is not, that student may not realize how their behavior is negatively affecting a relationship with the professor. Explicit mention of our expectations in syllabi or in class orientations could benefit both students and faculty members. Providing the reasoning for such expectations would not only give students the opportunity to comply, but would also make the expectations more acceptable to students. Opening up a conversation about faculty expectations and perceptions may even provide an opportunity for dialogue in which students offer their perceptions and expectations in return.

The present study was done in a public university in the Midwest. Studies in other regions of the United States and in other countries, as well as in different types of institutions such as private colleges or community colleges, would allow for comparisons and further conclusions. An important next step would also be to investigate students' perceptions of inappropriate behavior by faculty, in order to provide a balanced and more complete picture. Such a study could focus not only on classroom behaviors, but also include those that occur in one-on-one settings.

Incivility, both within and outside the walls of the classroom, tears at the fabric of our communities and at the important relationship between students and faculty members. Encountering on a daily basis behavior they consider uncivil discourages and disheartens faculty, causing some to withdraw in whatever fashion available to them. Understanding more clearly the student behaviors that faculty perceive as inappropriate and occurring regularly outside the classroom, and developing strategies to manage them, is a necessary step in addressing the larger issue of incivility in higher education.

\section{References}

Alexander-Snow, M. (2004). Dynamics of gender, ethnicity, and race in understanding classroom incivility. New Directions for Teaching and Learning, 99, 21-31.

Amanda, G. (1999). Coping with misconduct in the college classroom: A practical model. Asheville, NC: College Administration Publications, Inc.

Appleby, D. C. (1990). Family and student perceptions of irritating behavior in the college classroom. Journal of Staff, Program and Organizational Development, 8, 4146.

Bjorklund, W. \& Rehling, D. L. (2010). Student perceptions of incivility in the classroom. College Teaching, 58, 15-18.

Boice. B. (1996). Classroom incivilities. Research in Higher Education, 37(4), 453-85.
Clark, C. M. \& Springer, P. J. (2007). Thoughts on incivility: Student and faculty perceptions of uncivil behavior in nursing education. Nursing Education Perspectives, 28(2), 93-97.

Dechter, G. (2007, January 8). Not so long ago most college instructors were treated with dignity and respect. The Baltimore Sun, p. 1F.

Feldman, L. J. (2001). Classroom civility is another of our instructor responsibilities. College Teaching, 49, 137-40.

Hirshy, A. S. \& Braxton, J. S. (2004). Effects of student classroom incivilities on students. New Directions for Teaching and Learning, 99, 67-76.

Indiana University Center for Survey Research. (2000). A survey on academic incivility at Indiana 
$\begin{array}{lrr}\text { University: } & \text { Preliminary } & \text { report. } \\ \text { [Online]. } & \text { Retrieved } & \text { from }\end{array}$ http://www.indiana.edu/ csr/Civility PreReport.pdf

Jacoby, N. (1999). Employees say they've had enough of incivility, bad manners. CNNMoney. Retrieved from http://money.cnn.com/1999/11/29/li fe/q_manners/

Jones, T. (2004). The perils of Peter Parse: Facing the challenges of student incivility. The National Teaching \& Learning Forum, 13(5), 8-9.

Lunday, A. (2007, October 22). The manners maven. The JHU Gazette, 37(8). Retrieved from

http://www.jhu.edu/ gazette/2007/

22oct07/22manners.html
Morrisette, P. J. (2001, May 14). Reducing incivility in the university/college classroom. International Electronic Journal for Leadership in Learning, 5(4). Retrieved from http://www.ucalgary.ca/ iejll/volum e5/morrissette.html .

Rookstool, J. (2007). Fostering civility on campus. Washington, D.C.: Community College Press.

Sorcinelli, M. D. (1994). Dealing with troublesome behaviors in the classroom. In K. W. Prichard \& R. M. Sawyer (Eds.), Handbook of College Teaching: Theory and Application (pp. 365-373). Eastport Connecticut: Greenwood Press.

Young, J. (2003, August 8). Sssshhh. We're taking notes here. Chronicle of Higher Education, sec. A. 
Table 1:

Mean Ratings of the Degree of Inappropriateness of Student Behaviors (Ranked from Most I nappropriate to Least Inappropriate Behaviors) and Percentage of Faculty Responses Associated with each Rating

\begin{tabular}{|c|c|c|c|c|c|c|c|}
\hline Behavior & Mean & s.d. & $\begin{array}{c}1 \\
(\%)\end{array}$ & $\begin{array}{c}2 \\
(\%)\end{array}$ & $\begin{array}{c}3 \\
(\%)\end{array}$ & $\begin{array}{c}4 \\
(\%)\end{array}$ & $\begin{array}{c}5 \\
(\%) \\
\end{array}$ \\
\hline $\begin{array}{l}\text { Missing a scheduled } \\
\text { appointment }\end{array}$ & 3.95 & 1.07 & 2.3 & 9.8 & 16.5 & 33.1 & 38.3 \\
\hline $\begin{array}{l}\text { Wearing apparel with } \\
\text { explicit language or images }\end{array}$ & 3.89 & 1.20 & 3.0 & 14.3 & 17.3 & 21.8 & 43.6 \\
\hline $\begin{array}{l}\text { Insisting that you force } \\
\text { register them into an } \\
\text { already full course }\end{array}$ & 3.82 & 1.31 & 6.2 & 13.1 & 19.2 & 15.4 & 46.2 \\
\hline $\begin{array}{l}\text { Turning in a paper late and } \\
\text { asking not to be penalized } \\
\text { for being late }\end{array}$ & 3.74 & 1.21 & 6.8 & 10.5 & 17.3 & 33.1 & 32.3 \\
\hline Wearing revealing clothing & 3.45 & 1.27 & 6.1 & 14.3 & 20.5 & 23.5 & 28.0 \\
\hline $\begin{array}{l}\text { Asking if they missed anything } \\
\text { important }\end{array}$ & 3.37 & 1.42 & 13.5 & 17.3 & 18.8 & 19.5 & 30.8 \\
\hline $\begin{array}{l}\text { Requesting letters of } \\
\text { recommendation with } \\
\text { short notice }\end{array}$ & 3.25 & 1.16 & 5.3 & 25.2 & 24.4 & 29.0 & 16.0 \\
\hline Requesting a grade change & 2.67 & 1.36 & 22.4 & 32.1 & 17.2 & 13.4 & 14.9 \\
\hline $\begin{array}{l}\text { Requesting additional time, } \\
\text { after class is over, to } \\
\text { complete a test }\end{array}$ & 2.52 & 1.31 & 25.8 & 31.1 & 19.7 & 12.1 & 11.4 \\
\hline $\begin{array}{l}\text { Using office hours as an } \\
\text { opportunity to socialize } \\
\text { with instructor }\end{array}$ & 2.48 & 1.25 & 23.5 & 37.1 & 15.9 & 14.4 & 9.1 \\
\hline $\begin{array}{l}\text { Sending email or voicemails } \\
\text { requesting you to call them } \\
\text { back }\end{array}$ & 1.98 & 1.24 & 50.0 & 22.7 & 12.1 & 9.1 & 6.1 \\
\hline $\begin{array}{l}\text { Requesting that the instructor } \\
\text { inform them of their grade at } \\
\text { the end of the semester }\end{array}$ & 1.93 & 1.15 & 49.3 & 23.9 & 15.7 & 6.7 & 4.5 \\
\hline $\begin{array}{l}\text { Arriving at a scheduled } \\
\text { appointment on time }\end{array}$ & 1.10 & .54 & 96.2 & .8 & .8 & 1.5 & .8 \\
\hline $\begin{array}{l}\text { Requesting letters of } \\
\text { recommendation with } \\
\text { plenty of lead time }\end{array}$ & 1.07 & .50 & 97.0 & 1.5 & 0.0 & 0.0 & 1.5 \\
\hline
\end{tabular}


Table 2: Mean Ratings of the Frequency of Student Inappropriate Behaviors (Ranked from Most Frequently to Least Frequently Observed) and Percentage of Faculty Responses Associated with each Rating

\begin{tabular}{|c|c|c|c|c|c|c|c|}
\hline Behavior & Mean & s.d. & $\begin{array}{c}1 \\
(\%)\end{array}$ & $\begin{array}{c}2 \\
(\%)\end{array}$ & $\begin{array}{c}3 \\
(\%)\end{array}$ & $\begin{array}{c}4 \\
(\%)\end{array}$ & $\begin{array}{c}5 \\
(\%) \\
\end{array}$ \\
\hline $\begin{array}{l}\text { Arriving at a scheduled } \\
\text { appointment on time }\end{array}$ & 3.82 & .97 & 2.3 & 8.3 & 18.2 & 47.7 & 23.5 \\
\hline $\begin{array}{l}\text { Asking if they missed } \\
\text { anything important }\end{array}$ & 3.58 & 1.16 & 2.2 & 19.3 & 25.9 & 23.7 & 28.9 \\
\hline $\begin{array}{l}\text { Requesting letters of } \\
\text { recommendation with } \\
\text { plenty of lead time }\end{array}$ & 3.27 & 1.12 & 7.5 & 16.5 & 30.8 & 31.6 & 13.5 \\
\hline $\begin{array}{l}\text { Sending an e-mail or } \\
\text { voicemails requesting you call } \\
\text { them back }\end{array}$ & 3.22 & 1.29 & 7.5 & 29.1 & 20.1 & 20.9 & 22.4 \\
\hline $\begin{array}{l}\text { Turning a paper in late and } \\
\text { asking not be penalized for } \\
\text { being late }\end{array}$ & 2.88 & 1.36 & 18.2 & 27.3 & 19.7 & 18.2 & 16.7 \\
\hline $\begin{array}{l}\text { Requesting that the instructor } \\
\text { inform them of their grade at } \\
\text { the end of the semester }\end{array}$ & 2.87 & 1.28 & 14.9 & 29.1 & 25.4 & 15.7 & 14.9 \\
\hline $\begin{array}{l}\text { Missing a scheduled } \\
\text { appointment }\end{array}$ & 2.72 & 1.12 & 11.2 & 39.6 & 23.1 & 18.7 & 7.5 \\
\hline Wearing revealing clothing & 2.62 & 1.20 & 15.9 & 39.4 & 21.2 & 13.6 & 9.8 \\
\hline Requesting a grade change & 2.43 & .97 & 11.1 & 52.6 & 23.7 & 7.4 & 5.2 \\
\hline $\begin{array}{l}\text { Requesting letters of } \\
\text { recommendation with } \\
\text { short notice }\end{array}$ & 2.42 & 1.14 & 22.7 & 37.1 & 19.7 & 15.9 & 4.5 \\
\hline $\begin{array}{l}\text { Insisting that you force } \\
\text { register them into an } \\
\text { already full course }\end{array}$ & 2.17 & 1.29 & 41.7 & 25.8 & 13.6 & 11.4 & 7.6 \\
\hline $\begin{array}{l}\text { Requesting additional time, } \\
\text { after class is over, to } \\
\text { complete a test }\end{array}$ & 2.09 & 1.12 & 37.3 & 32.8 & 17.9 & 7.5 & 4.5 \\
\hline $\begin{array}{l}\text { Wearing apparel with } \\
\text { explicit language or images }\end{array}$ & 2.09 & 1.07 & 31.8 & 43.9 & 11.4 & 9.1 & 3.8 \\
\hline $\begin{array}{l}\text { Using office hours as an } \\
\text { opportunity to socialize } \\
\text { with instructor }\end{array}$ & 2.05 & 1.08 & 35.3 & 40.6 & 12.8 & 6.8 & 4.5 \\
\hline
\end{tabular}

\section{Endnotes}

${ }^{1}$ This study is part of a larger series of studies on uncivil behavior both within the classroom and beyond the classroom walls. In order to distinguish between the public behavior that occurs during a class session, and the private, interpersonal behavior that occurs outside of class between an individual student and an instructor, the researchers have labeled uncivil behavior that occurs in a private setting as "inappropriate", reserving the term "incivility" for publicly uncivil behavior.

2 This $11.7 \%$ response rate is lower than ideal (although not unusually so) and is very likely a result of the timing of the survey, which was very close to the end of the semester, a notoriously challenging time for faculty and students. In addition, faculty members received no incentive to participate in the study. 
Wendy Bjorklund is an Assistant Professor in the Communication Studies Department at St. Cloud State University in St. Cloud, MN. Her primary teaching areas are organizational communication, communication in the workplace and relational conflict management. Her research interests focus on interpersonal conflict in the workplace and she is a mediator/conflict coach.

Diana Rehling is a Professor in the Communication Studies Department at St. Cloud State University in St. Cloud, MN. Her primary teaching areas include listening, nonverbal communication, small group, theory and research methods. Her current research projects focus on listening and the role of digital media in students' lives. 